\title{
START WRITING IN A REFLECTIVE JOURNAL: A STRATEGY TO ENHANCE CRITICAL THINKING SKILLS OF HEALTH PRACTITIONERS
}

\author{
Joko Gunawan* \\ ${ }^{1}$ Indonesian Nurses Association of Belitung \\ ${ }^{2}$ Akademi Keperawatan Pemerintah Kabupaten Belitung \\ ${ }^{3}$ Belitung Raya Foundation
}

Accepted: 17 November 2017

*Correspondence:

Joko Gunawan, S.Kep. Ners

E-mail : jokogunawan2015@gmail.com

Copyright: (C) the author(s), YCAB publisher and Public Health of Indonesia. This is an open-access article distributed under the terms of the Creative Commons Attribution Non-Commercial License, which permits unrestricted non-commercial use, distribution, and reproduction in any medium, provided the original work is properly cited.

\section{Dear Editor,}

Due to the complexity of the today's health problems, increased aging population, and complex diseases, public health and nurse professionals, as frontline health workers, are required to use their critical thinking skills to make decision. In fact, most of the time they act effectively without using critical thinking as many decisions are mainly based on habit and have a minimum reflection, ${ }^{1}$ which may impact to poor health outcome. Therefore, the strategy to foster critical thinking skill is needed.

One of the ways to develop critical thinking is to start writing in a reflective journal. A consistent routine of writing at least weekly in a journal can improve critical thinking. ${ }^{2}$ Writing about critical incidents, complex situations that require decision-making, as well as emotions and feelings about interactions and events stimulate analysis, synthesis, judgment, and creativity that are components of critical thinking. Literature stated that public health and nurses have more confidence in analyzing information, determining relevance, making connections, selecting appropriate information, and applying relevant knowledge and outcomes in the journal format than implementing those in the care plan format; ${ }^{3}$ and the most important benefit is that the process of writing is linking the theory and practice. ${ }^{4}$

To start writing in journal, public health and nurse practitioners can create a journal club, as a way for them to engage in a discussion group with colleagues. Articles on public health, leadership, management, and evidence-based practice can be presented. Public health and nurse practitioners can take turns engaging the group in dialogue based on an article. In discussing the article, critical thinking skills are used to analyze, critique, and 
draw parallels from the article to the practice environment. ${ }^{2}$

In addition, by writing in a journal, it will help public health and nurse practitioners to identify health problems, set goals and tract progress towards the goals, reflect in recent lessons from personal or professional life, and mark accomplishment and failures, even to create histories. ${ }^{5}$ In summary, writing in a reflective journal is very useful to increase the critical thinking skills. "If not public health and nurse practitioners to start writing today, then who else?"

\section{REFERENCES}

1. Papathanasiou IV, Kleisiaris CF, Fradelos EC, Kakou K, Kourkouta L. Critical thinking: the development of an essential skill for nursing students. Acta Informatica Medica. 2014; 22(4):283.

2. Profetto-McGrath J. Critical thinking and evidence-based practice. Journal of Professional Nursing. 2005;21(6): 364-371.

3. Marchigiano G, Eduljee N, Harvey K. Developing critical thinking skills from clinical assignments: a pilot study on nursing students' selfreported perceptions. Journal of Nursing Management. 2011;19(1): 143-152.

4. Gunawan J. Bringing Nursing Theories into practice: If not Nurses, Who else? A Perspective from a Nurse Joko Gunawan. 2015.

5. Gunawan J. Buku Saku METODOLOGI PENELITIAN KESEHATAN: Pedoman perumusan masalah penelitian untuk mahasiswa keperawatan dan kebidanan: Penerbit CV. Violet Indah Sejahtera; 2017.

Cite this article as: Gunawan J. Start Writing in a Reflective Journal: A Strategy to Enhance Critical Thinking Skills of Health Practitioners. Public Health of Indonesia 2017; 3(4):160-161 